\title{
LEVELS OF SERUM IMMUNOGLOBULINS IN PATIENTS WITH RHEUMATOID ARTHRITIS
}

BY

\author{
R. MARCOLONGO, JR., A. CARCASSI, F. FRULLINI, G. BIANCO, \\ AND A. BRAVI \\ From the Department of Internal Medicine, University of Siena, Italy
}

Quantitative and qualitative modifications of the plasma proteins are of particular importance among the systemic manifestations of rheumatoid arthritis. Increase of $a_{2}$-and $\gamma$-globulins may be found in most patients (Ropes, Perlmann, Kaufman, and Bauer, 1954) in relation to the onset, evolution, and activity of the disease (Bonomo, 1957). The most important pattern consists generally of a predominant hypergammaglobulinaemia, but this may not be considered a specific finding of rheumatoid arthritis because it is a common serological pattern of many diseases involving chronic inflammatory processes (Bonomo, 1957; Claman and Merrill, 1965). This indicated that a more thorough survey of this globulin fraction, which is carrier of nearly all the serum antibody activity (Heremans, 1960), should be undertaken. The serum gammaglobulins form a heterogenous system and the main components $(\gamma \mathrm{G}, \gamma \mathrm{A}, \gamma \mathrm{M}$, and $\gamma \mathrm{D})$ can be distinguished on the basis of different antigenic groups (Heremans, 1960; Fahey, 1962; Claman and Merrill, 1964; Fahey and McKelvey, 1965). Immuno-electrophoresis is a useful method of separating fractions and evaluating the presence and the nature of any abnormal components in the serum, but this technique is based on a semi-quantitative method and may not give precise quantitative indications of the changes in each of the fractions. Recently, by using the radial immunodiffusion technique, it has been possible to study and estimate quantitatively each single gammaglobulin fraction by means of specific anti-sera directed against the corresponding antigenic group (Heremans, Vaerman, Carbonara, Rodhain, and Heremans, 1963; Claman and Merrill, 1964).
The purpose of this paper is to study the sera of patients with rheumatoid arthritis by means of immuno-electrophoresis on agar and immunodiffusion methods to define alterations immunologically and to establish their specificity and their relationship with the activity and duration of the disease. Moreover, it appeared to be of interest to check in the tested sera the possible relations between the levels of $\gamma \mathrm{M}$ fraction, to which rheumatoid factor belongs, and the positivity of the agglutination reaction.

\section{Material and Methods \\ Human Subjects}

(1) Twenty volunteer medical students and nurses without signs of illness were used as controls.

(2) 35 patients with classic rheumatoid arthritis, clinically and radiologically ascertained according to the A.R.A. criteria, and positive latex-fixation tests varying from $1: 40$ to $1: 5120$.

(3) Eight patients with rheumatoid arthritis and negative latex-fixation tests.

(4) Twenty patients hospitalized with osteo-arthrosis, with positive latex-fixation tests varying from 1:40 to $1: 320$.

Serum Samples.-Sera free from haemolysis were immediately utilized or stored at $-40^{\circ} \mathrm{C}$. and thawed before use.

Agglutination Reaction.-The presence of rheumatoid factor was investigated in all sera by the latex-agglutination slide test (Hyland Laboratories).

Immuno-electrophoresis. - This was carried out with the microapparatus of Scheidegger (1955). Electrophoretic separation was performed on 1.5 per cent. agar in $0.1 \mathrm{M}$ veronal buffer $\mathrm{pH} 8$, using microscope slides 
$(75 \times 25 \mathrm{~mm}$. $)$ as support. We used an immune serum supplied by the Pasteur Institute (No. AH 419 2A). The content of each fraction was considered to be increased only when the corresponding precipitation band was thickened and sometimes lengthened compared with the corresponding band of a standard control serum (Grabar and Burtin, 1960).

Radial Immunodiffusion.-We used the equipment and reagents supplied by Hyland Laboratories. Each immunodiffusion plate contains six wells which are filled with the sample of serum to be examined by means of a thin capillary pipette or a microsyringe. The tip of the pipette must touch the bottom of the well. The serum is then allowed to flow by gravity, so that the well is filled to the level of the agar surface. In the same way the other wells are filled with three different dilutions of each globulin at known concentrations. The immunoplates are hermetically sealed and allowed to incubate at room temperature $\left(20-25^{\circ} \mathrm{C}\right.$.) for $16 \mathrm{hrs}$. After incubation the diameters of each precipitation ring (Fig. 1) are measured by placing the plates under a specially calibrated viewer, aligning one side of the ring with the zero mark on the grid. The values obtained on reading the standard solutions were plotted on semilogarithmic graph paper, reproducing the precipitate ring diameters on the horizontal scale. This gave a standard curve which was used to calculate the concentration of the various fractions examined.

\section{Results}

\section{Immuno-electrophoresis Analysis}

We observed no considerable constant increase in the precipitation line corresponding to $\gamma \mathrm{M}$ fraction in the sera of sero-positive compared with seronegative cases, of patients with osteo-arthrosis, or of normal controls. A more or less evident accentuation of the $\gamma \mathrm{M}$ band was seen in only a limited number of sero-positive rheumatoid patients ( 7 out of 35 cases), but this was also observed in two patients with sero-negative rheumatoid arthritis, four with osteo-arthrosis, and four normal subjects.

The amount of $\gamma \mathrm{A}$ appeared to exceed the normal concentration in five sero-positive cases and one
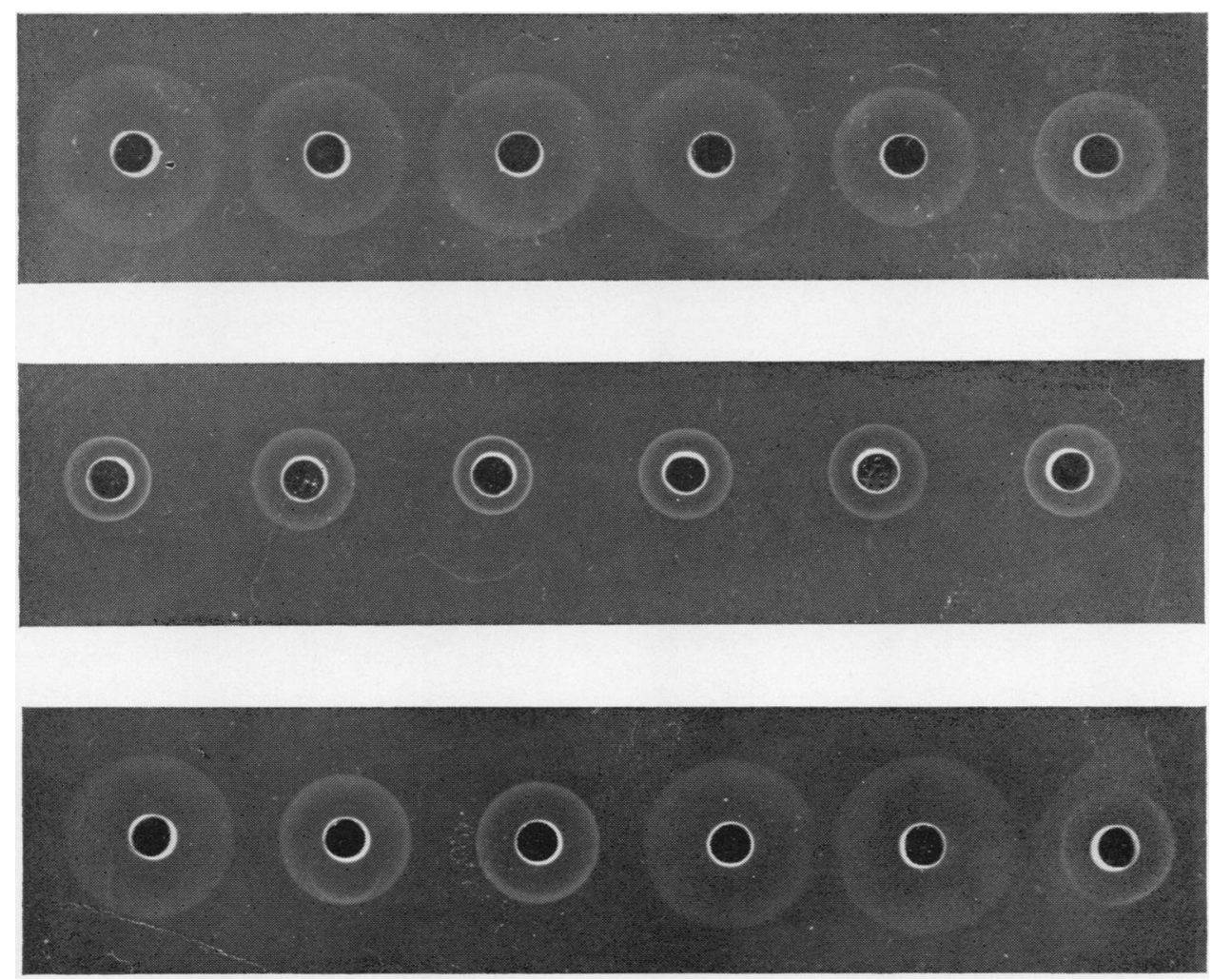

Fig. 1.-Quantitative gel diffus:on test, showing diffusion rings obtained in "immunoplates" with sera from different rheumatoid patients. Photographed at 16 hrs. A normal serum used as control is shown on the right. 
sero-negative case of rheumatoid arthritis and in two healthy subjects. It must be emphasized that the band corresponding to this fraction is generally covered by the $\gamma \mathrm{G}$ line so that its morphology is often very hard to evaluate.

The $\gamma \mathrm{G}$ fraction was found to be increased in twelve cases of sero-positive rheumatoid arthritis and in one case of osteo-arthrosis.

\section{Radial Immunodiffusion}

The quantitative results are shown in the Table and in Figs 2 to 4 .

\section{Discussion}

Immuno-electrophoretic analysis of sero-positive rheumatoid sera shows the absence of abnormal pathological constituents or specific immunological anomalies and gives precipitation bands similar to

TABLE

RESULTS OF RADIAL IMMUNODIFFUSION STUDIES

\begin{tabular}{|c|c|c|c|c|c|c|c|c|c|c|}
\hline \multirow{2}{*}{$\begin{array}{c}\text { Gamma Globulin } \\
\text { Fraction }\end{array}$} & \multirow{2}{*}{\multicolumn{7}{|c|}{ Serum }} & \multicolumn{3}{|c|}{ Value (mg./ml.) } \\
\hline & & & & & & & & \multicolumn{2}{|c|}{ Mean \pm S.D. } & \multirow{2}{*}{$\frac{\text { Range }}{7 \cdot 1-17 \cdot 1}$} \\
\hline \multirow{3}{*}{$\stackrel{\gamma \mathrm{G}}{\text { (Fig. 2) }}$} & Normal .. & . & . & $\ldots$ & . & $\ldots$ & $\ldots$ & $12 \cdot 33$ & $2 \cdot 26$ & \\
\hline & Rheumatoid Arthritis & $\cdots$ & $\ldots$ & \multicolumn{4}{|c|}{$\begin{array}{l}\text { Sero-positive } \\
\text { Sero-negative }\end{array}$} & $\begin{array}{l}15 \cdot 44 \\
13 \cdot 97\end{array}$ & $\begin{array}{l}6 \cdot 42 \\
4 \cdot 08\end{array}$ & $\begin{array}{l}7 \cdot 1-22 \cdot 4 \\
9 \cdot 2-19 \cdot 2\end{array}$ \\
\hline & Osteo-arthrosis .. & $\cdots$ & $\cdots$ & $\cdots$ & . & . & $\cdots$ & $12 \cdot 62$ & $2 \cdot 85$ & $7 \cdot 2-18 \cdot 0$ \\
\hline \multirow{3}{*}{$\begin{array}{c}\gamma \mathrm{M} \\
\text { (Fig. 3) }\end{array}$} & Normal .. & $\cdots$ & $\cdots$ & $\cdots$ & $\cdots$ & $\cdots$ & $\cdots$ & $1 \cdot 19$ & $0 \cdot 72$ & $0 \cdot 50-3 \cdot 20$ \\
\hline & Rheumatoid Arthritis & $\cdots$ & $\cdots$ & \multicolumn{4}{|c|}{$\begin{array}{l}\text { Sero-positive } \\
\text { Sero-negative }\end{array}$} & $\begin{array}{l}1 \cdot 32 \\
1 \cdot 19\end{array}$ & $\begin{array}{l}0 \cdot 80 \\
1 \cdot 00\end{array}$ & $\begin{array}{l}0 \cdot 25-3 \cdot 75 \\
0 \cdot 25-3 \cdot 30\end{array}$ \\
\hline & Osteo-arthrosis .. & $\cdots$ & . & . & $\cdots$ & . & $\ldots$ & $1 \cdot 18$ & 0.45 & $0 \cdot 67-2 \cdot 20$ \\
\hline \multirow{3}{*}{$\underset{(\mathrm{Fig} .4)}{\gamma \mathrm{A}}$} & Normal .. & $\cdots$ & $\cdots$ & $\cdots$ & $\cdots$ & $\cdots$ & $\cdots$ & $2 \cdot 92$ & 0.83 & $0 \cdot 53-5 \cdot 50$ \\
\hline & Rheumatoid Arthritis & $\ldots$ & $\cdots$ & \multicolumn{4}{|c|}{$\begin{array}{l}\text { Sero-positive } \\
\text { Sero-negative }\end{array}$} & $\begin{array}{l}3 \cdot 85 \\
4 \cdot 19\end{array}$ & $\begin{array}{l}1 \cdot 70 \\
1 \cdot 91\end{array}$ & $\begin{array}{l}0 \cdot 43-7 \cdot 75 \\
1 \cdot 18-6 \cdot 50\end{array}$ \\
\hline & Osteo-arthrosis .. & $\cdots$ & $\cdots$ & $\cdots$ & $\cdots$ & $\cdots$ & . & $2 \cdot 97$ & $1 \cdot 07$ & $1 \cdot 00-6 \cdot 00$ \\
\hline
\end{tabular}

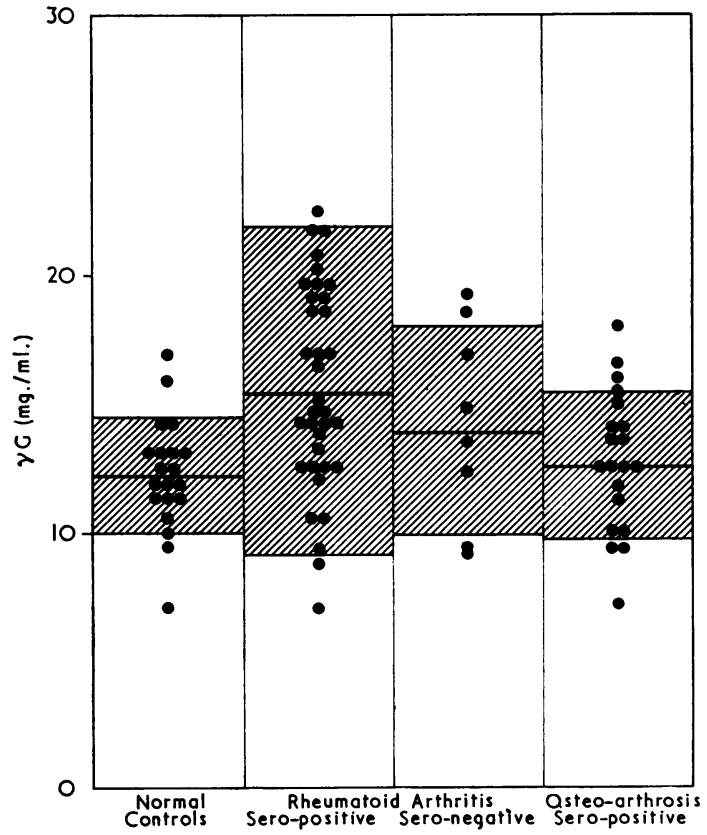

Fig. 2.-Serum levels of $\gamma \mathrm{G}$ immunoglobulins.

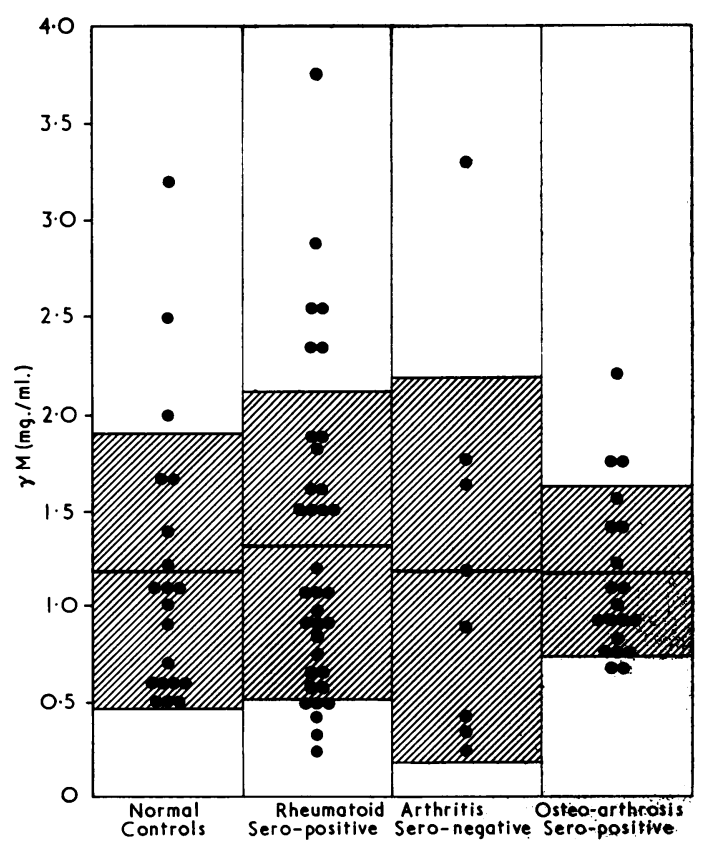

Fig. 3.-Serum levels of $\gamma \mathbf{M}$ immunoglobulins. 


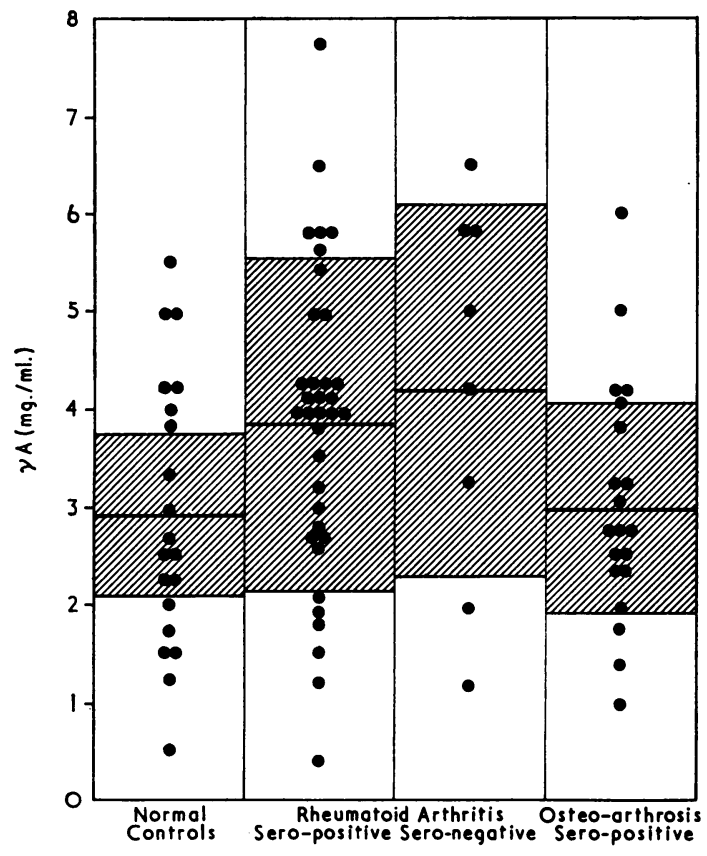

Fig. 4.-Serum levels of $\gamma \mathrm{A}$ immunoglobulins.

those obtained in many other diseases.

The inconstant or absent accentuation of the precipitation line corresponding to $\gamma \mathrm{M}$ fraction is noteworthy. In contrast with the observations of Cleve (1958), Mackiewicz and Fenrych (1961,) Zanussi, Invernizzi, del Giacco, and Luporini (1961), Caronia, Martelli, and Pitucco (1962), and Sfikakis and Loukopoulos (1964), our results appear to agree with the data of Francq, Eyquem, Podliachouk, and Jacqueline (1959), Podliachouk, Francq, Eyquem, and Jacqueline (1960), Eyquem, Jacqueline, Podliachouk, and Francq (1960), and Fallet, Meyer, and Scheidegger (1961), who think that immuno-electrophoretic analysis of rheumatoid sera is not able to reveal a significant increase of $\gamma \mathrm{M}$. It may sometimes be possible to find a very marked increase of $\gamma \mathrm{M}$ in sero-negative patients and in some healthy controls, but an increase of this fraction was not observed in sero-positive cases. The results obtained with the immunodiffusion technique have also confirmed the presence in rheumatoid sera of $\gamma \mathrm{M}$ levels which do not differ significantly from the normal. Similar findings were obtained in patients with sero-negative rheumatoid arthritis and sero-positive osteo-arthrosis. Hong and West (1964) have also obtained normal values in sero-positive rheumatoid patients, while Claman and Merrill (1966) found an increase in 17 per cent. of rheumatoid sera. In agreement with Heremans (1960) and Eyquem and others
(1960), we believe that this finding may be explained by the fact that variations in concentrations of rheumatoid factor, which represents roughly 10 per cent. of the total quantity of $\gamma \mathrm{M}$ globulin, are so slight as to have only a negligible and inconstant effect on the total amount of $\gamma \mathrm{M}$. Further evidence that the quantity of $\gamma \mathrm{M}$ is often independent of the presence or absence of rheumatoid factor in the serum is provided by our unsuccessful attempts to establish the existence of a relationship between the $\gamma \mathrm{M}$ concentration and the serum agglutination titre (Fig. 5).

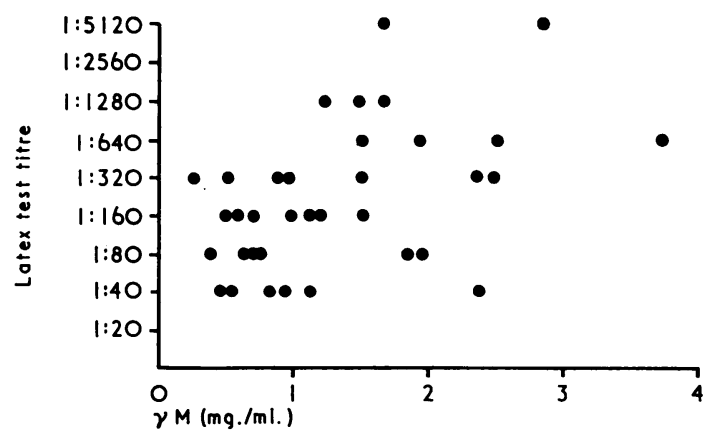

Fig. 5.-Correlation between latex test titre and values of $\gamma \mathbf{M}$ in sero-positive rheumatoid patients.

As for the alterations involving $\gamma \mathrm{A}$, our results agree with those of Hong and West (1964) and Claman and Merrill (1965, 1966). Cases of seronegative rheumatoid arthritis showed significantly high titres of $\gamma \mathrm{A}$. The mechanism of this increase in $\gamma \mathrm{A}$ levels are still unknown. Moreover, the fact that allergic type antibodies as well as rheumatoid factor are in some cases associated with this fraction (Heremans and Vaerman, 1962; Heimer and Levin, 1964) complicates the subject, as it is not unknown whether this immunoglobulin has other specific functions or not. An increase in $\gamma \mathrm{A}$ has been observed in some diseases, while a marked deficiency has been reported in other diseases and also in healthy subjects (Fahey and Lawrence, 1963; Rockey, Hanson, Heremans, and Kunkel, 1964; Wollheim and Williams, 1965). Claman and Merrill (1965) believe that $\gamma \mathrm{A}$ is the most labile of the immunoglobulins in comparison with the other fractions.

The results obtained with the immunodiffusion technique confirmed the marked and statistically significant increase of $\gamma \mathrm{G}$ levels in patients with sero-positive rheumatoid arthritis, while normal values were obtained in cases of sero-negative rheumatoid arthritis and osteo-arthrosis. The $\gamma \mathrm{G}$ fraction is increased in other collagen diseases and 
in many pathological conditions, such as liver diseases, infectious diseases, and some systemic haemopathies (Heremans and others, 1963).

Marked fluctuations of $\gamma \mathrm{A}$ and $\gamma \mathrm{G}$ sometimes occurred in our patients. This phenomenon has also been found in healthy subjects and it may be difficult to establish the normal values of the different immunoglobulins because of this variability in serum levels. The degree of aggregation and polymerization of the globulins may produce a lower degree of immunodiffusion and thus false low results, especially in cases of rheumatoid arthritis in which $22 \mathrm{~S}$ circulating complexes may be present with variable frequency (Claman and Merrill, 1966).

Hyperplasia of the reticulo-endothelial system may be important in the pathogenesis of hypergammaglobulinaemia (Bonomo, 1957). Serum immunoglobulin levels represent the equilibrium between catabolism and synthesis in normal conditions, and the amount of immunoglobulins appears to be related to many factors, such as environment, the antigenic stimuli, and the genetic regulation of protein synthesis (McKelvey and Fahey, 1965; Wollheim and Williams, 1965). Several diseases may interfere with the regulation of serum immunoglobulin levels, through environmental or metabolic factors. For instance, high immunoglobulin concentrations are observed in infections involving increased antigenic stimulation and in chronic inflammation in which immunoglobulin catabolism is increased (Fahey and Lawrence, 1963; Andersen, 1964). In rheumatoid arthritis and other collagen diseases, increased immunoglobulin synthesis has been demonstrated by radio-active isotopes (Mills, Calkins, and Cohen, 1961; Andersen, 1964).

Our series of patients is too small to determine whether the $\gamma \mathrm{A}$ and $\gamma \mathrm{G}$ levels are significantly related to serological and radiological alterations and disease activity in individual subjects. Bonomo (1957) suggested that the dysproteinaemic alterations may be related to the progressive clinical involvement and the course of the disease. Claman and Merrill (1966) found no correlation between immunoglobulin levels and the duration of rheumatoid arthritis.

In our cases, the three fractions of immunoglobulins behave as if independently correlated with the processes of synthesis. Furthermore, the absence of a parallel increase for each single component is a common finding in the group of diseases in which increases in gammaglobulins are observed (Heremans and others, 1963). Some investigators have stressed that the nature of the antigenic stimulation may be an important factor in determining the type of response of each fraction (Heremans and others, 1963).

It thus appears that alterations in the immunoglobulins in rheumatoid arthritis are frequent, but not consistent. The same changes are detectable with variable frequency in several diseases and it is therefore impossible to make a serological diagnosis on the basis of the globulin pattern alone. There was a significantly marked increase in $\gamma \mathrm{A}$ and $\gamma \mathrm{G}$ in many of our cases, but this appears to have no specific significance, and should merely be considered as an aspecific index of the various humoural alterations observable in rheumatoid arthritis.

\section{Summary}

Serum immunoglobulins $(\gamma \mathrm{G}, \gamma \mathrm{A}, \gamma \mathbf{M})$ were studied in 35 cases with sero-positive and seronegative rheumatoid arthritis and in subjects with osteo-arthrosis and a positive latex test, by means of immuno-electrophoresis and the radial immunodiffusion method. Raised $\gamma \mathrm{A}$ levels were found in most of the sero-positive and sero-negative rheumatoid patients, but an increase of $\gamma \mathrm{G}$ was found only in sero-positive rheumatoid patients. The $\gamma \mathrm{M}$ values were normal.

There was no correlation between the immunoglobulin levels and the clinical course and duration of the disease. The alterations observed are not specific for rheumatoid arthritis as similar patterns occur in other diseases. The pathogenetic significance of the increase in various $\gamma$ fractions is still to be clarified. The increased tendency to respond to immunological stimuli and to the development of autoimmune and delayed hypersensitivity phenomena characteristic of rheumatoid arthritis may be responsible for the changes observed.

This work was supported by a grant from the Consiglio Nazionale delle Ricerche, Roma. We are grateful to Mr. C. Marsili for his valuable technical assistance.

\section{REFERENCES}

Andersen, S. B. (1964). “Metabolism of Human Gamma Globulin”. Blackwell, Oxford.

Bonomo, L. (1957). Ann. rheum. Dis., 16, 340 (Hyperglobulinaemia in rheumatoid arthritis).

Caronia, F., Martelli, M., and Pitucco, G. (1962). Boll. Soc. ital. Biol. sper., 38, 150 (Contributo alla conoscenza del quadro sieroproteico di pazienti affetti da artrite reumatoide: immunoelettroforesi con impiego di immunsiero antisiero umano normale (ante-SUN) e di immunisiero antisiero di pazienti con artrite reumatoide (anti-SAR)). 
Claman, H. N., and Merrill, D. (1964). J. Lab. clin. Med., 64, 685 (Quantitative measurement of human gamma-2, beta-2A, and beta-2M serum immunoglobulins).

(1965). J. Allerg., 36, 463 (Hypergammaglobulinaemia-the role of the immunoglobulins $\gamma \mathrm{G}, \gamma \mathrm{A}, \gamma \mathrm{M})$.

_ (1966). J. Lab. clin. Med., 67, 850 (Serum immunoglobulins in rheumatoid arthritis).

Cleve, H. (1958). Z. Rheumaforsch., 17, 350 (Neuere immunoelektrophoretische Untersuchungen im Serum Rheumakranker).

Eyquem, A., Jacqueline, F., Podliachouk, L., and Francq, J. C. (1960). Rev. franc. Étud. clin. biol., 5, 58 (Problèmes immunologiques de la polyarthrite chronique évolutive).

Fahey, J. L. (1962). Advanc. Immunol., 2, 41 (Heterogeneity of $\gamma$-globulins).

— and Lawrence, M. E. (1963). J. Immunol., 91, 597 (Quantitative determination of 6.6 $\gamma$-globulins, $\beta_{2 \mathrm{H}}$-globulins, and $\gamma_{2}$-macroglobulins in human serum).

— and McKelvey, E. M. (1965). Ibid., 94, 84 (Quantitative determination of serum immunoglobulins in antibody-agar plates).

Fallet, G. H., Meyer, E., and Scheidegger, J. J. (1961). Rev. franc. Étud. clin. biol., 6, 537 (La réaction de fixation au latex (FII L.P.) dans les affections rhumatismales et non rhumatismales).

Francq., J. C., Eyquem, A., Podliachouk, L., and Jacqueline, F. (1959). Ann. Inst. Pasteur, 96, 413 (Étude immunoélectrophorétique des rhumatismes inflammatoires chroniques).

Grabar, P., and Buttin, P. (1960). "Analyse immuno-électrophorétique”. Masson, Paris.

Heimer, R., and Levin, F. M. (1964). Arthr. and Rheum., 7, 738 (abstr.) Gamma ${ }_{1 \mathrm{~A}}$ and gamma 2 rheumatoid factors).

Heremans, J. F. (1960). "Les globulines sériques du système gamma". Éditions Arscia, Brussels. and Vaerman, J. P. (1962). Nature (Lond.), 193, 1091 ( $\beta_{2 \mathrm{~A}}$-globulin as a possible carrier of allergic reaginic activity).

— - Carbonara, A. O., Rodhain, J. A., and Heremans, M. T. (1963). In "Protides of the Biological Fluids: Prodeedings of the Tenth Colloquium, Bruges 1962", ed. H. Peeters, p. 108. Elsevier, Amsterdam and New York.

Hong, R., and West, C. D. (1964). Arthr. and Rheum., 7, 128 (Gamma-1 globulin levels in rheumatic fever).

Mackiewicz, S., and Fenrych, W. (1961). Ann. rheum Dis., 20, 265. (Immuno-electrophoretic analysis of proteins in serum and synovial fluid in rheumatoid arthritis and ankylosing spondylitis).

McKelvey, E. M., and Fahey, J. L. (1965). J. clin. Invest., 44, 1778 (Immunoglobulin changes in disease: quantitation on the basis of heavy polypeptide chains, $\operatorname{IgG}(\gamma \mathrm{G}), \operatorname{IgA}(\gamma \mathrm{A})$, and $\operatorname{IgM}(\gamma \mathrm{M})$, and of light polypeptide chains, type $\mathbf{K}$ (I) and type L (II) ).

Mills, J. A., Calkins, E., and Cohen, A. S. (1961). Ibid., 40, 1926 (The plasma disappearance time and catabolic half-life of $\mathbf{I}^{131}$-labeled normal human gamma globulin in amyliodosis and in rheumatoid arthritis).

Podliachouk, L., Francq, J. C., Eyquem, A., and Jacqueline, F. (1960). Ann. Inst. Pasteur, 98, 90 (Antigénicité des facteurs sérologiques de la polyarthrite chronique évolutive).

Rocbey, J. H., Hanson, L. A., Heremans, J. F., and Kunkel, H. G. (1964). J. Lab. clin. Med., 63, 205 (Beta $_{2 \mathrm{~A}}$ aglobulinemia in two healthy men).

Ropes, M. W., Perlmann, G. E., Kaufman, D., and Bauer, W. (1954). J. clin. Invest., 33, 311 (The electorphoretic distribution of proteins in plasma in rheumatoid arthritis).

Scheidegger, J. J. (1955). Int. Arch. Allerg., 7, 103 (Une microméthode de l'immunoélectrophorèse).

Sfikakis, P., and Loukopoulos, D. (1964). Z. Immun.-u. Allergforsch., 126, 332 (Serum B B ${ }_{2-}$ globulins and serological activity in patients with rheumatoid arthritis).

Wollheim, F. A., and Williams, R. C. (1965). J. Lab. clin. Med., 66, 433 (Immunoglobulin studies in six kindreds of patients with adult hypogammaglobulinemia).

Zanussi, C., Invernizzi, F., del Giacco, G. S., and Luporini, G. (1961). Boll. Ist. sieroter. milan., 40, 494 (L'immunoelettroforesi del siero e di altri liquidi biologici. Nota 2: In condizioni patologiche). 
Taux sériques des immunoglobulines chez des malades atteints d'arthrite rhumatismale.

\section{RÉSUMÉ}

On étudia les immunoglobulines sériques $(\gamma \mathrm{G}, \gamma \mathrm{A}, \gamma \mathrm{M})$ en 35 cas d'arthrite rhumatismale séropositive et séronégative et chez des sujets atteints d'ostéoarthrose accusant le test au latex positif, au moyen de l'immunoélectrophorèse et de la méthode d'immunodiffusion radiale. Des taux élevés de la $\gamma \mathrm{A}$ furent trouvés dans la plupart des cas rhumatismaux séropositifs et séronégatifs, mais l'augmentation de la $\gamma \mathrm{G}$ ne fut trouvé que chez des malades atteints d'arthrite rhumatismale séropositive. Les valeurs de la $\gamma \mathrm{M}$ furent mormales.

On ne trouva pas de corrélation entre les taux des immunoglobulines et l'évolution ou la durée de la maladie. Les altérations observées ne sont pas spécifiques de l'arthrite rhumatismale et on peut voir des tableaux similaires dans d'autres maladies. L'importance pathogénique de l'augmentaiton de diverses fractions $\gamma$ reste à éclaircir. La tendance augmentée à répondre à la stimulation immunologique et à développer des phénomènes d'hypersensibilité autoimmune et retardée qui caractérisent l'arthrite rhumatismale, peut être responsable des altérations observées.
Niveles séricos de las inmunoglobulinas en enfermos con artritis reumatoide

\section{SUMARIO}

Se estudiaron las inmunoglobulinas séricas $(\gamma \mathrm{G}$, $\gamma \mathrm{A}, \gamma \mathrm{M})$ en 35 casos de artritis reumatoide seropositiva $\mathrm{y}$ seronegativa y en sujetos con osteoartrosis con el test de latex positivo, por medio de inmunoelectroforesis y del método de inmunodifusión radial. Se encontraron valores aumentados de la $\gamma \mathrm{A}$ en la mayoría de los casos reumatoides seropositivos $\mathrm{y}$ seronegativos, pero el aumento de la $\gamma \mathrm{G}$ se vió sólo en enfermos con artritis reumatoide seropositiva. Los valores de la $\gamma \mathrm{M}$ fueron normales.

No se halló correlación entre los niveles de las inmunoglobulinas y la evolución o la duración de la enfermedad. Las alteraciones observadas no son específicas para la artritis reumatoide ya que cuadros similares pueden observarse en otras enfermedades. La importancia patógena del aumento de varias fracciones $\gamma$ queda por aclarar. La tendencia aumentada a responder a estímulos immunológicos y a desarrolar fenómenos de hipersensibilidad autoimmune y demorada, que caracterizan la artritis reumatoide, puede ser responsable de las alteraciones observadas. 